\title{
In vitro and in vivo effects of a nutrient mixture on breast cancer progression
}

\author{
M.W. ROOMI, T. KALINOVSKY, N.M. ROOMI, J.CHA, M. RATH and A. NIEDZWIECKI \\ Dr. Rath Research Institute, Santa Clara, CA 95050, USA
}

Received January 13, 2014; Accepted March 17, 2014

DOI: 10.3892/ijo.2014.2379

\begin{abstract}
Long-term survival of patients with breast cancer remains poor, due to metastasis and recurrence. We investigated the effects of a novel nutrient mixture (NM) containing ascorbic acid, lysine, proline and green tea extract in vitro and in vivo on 4T1 murine breast cancer, a representative model for metastatic breast cancer. After one week of isolation, 5-6-week-old female Balb/C mice were inoculated with $5 \times 10^{5} 4 \mathrm{~T} 1$ cells into the mammary pad and randomly divided into two groups; the control group was fed a regular diet and the NM group a regular diet supplemented with $0.5 \%$ NM. After four weeks, the mice were sacrificed and their tumors, lungs, livers, kidneys, hearts and spleens were excised and processed for histology. Dimensions (length and width) of tumors were measured using a digital caliper, and the tumor burden was calculated using the following formula: $0.5 \mathrm{x}$ length $\mathrm{x}$ width. We also tested the effect of NM in vitro on 4T1 cells, measuring cell proliferation by MTT assay, MMP secretion by zymography, invasion through Matrigel, migration by scratch test and morphology by H\&E staining. NM inhibited tumor weight and burden of $4 \mathrm{~T} 1$ tumors by $50 \%(\mathrm{p}=0.02)$ and $53.4 \%$ ( $\mathrm{p} \leq 0.0001)$, respectively. Lung metastasis was profoundly inhibited by NM supplementation: mean number of colonies was reduced by $87 \%(\mathrm{p}<0.0001)$ and mean weight of lungs by $60 \%(\mathrm{p}=0.0001)$ compared to control mice. Metastasis to liver, spleen, kidney and heart was significantly reduced with NM supplementation. In vitro, NM exhibited $50 \%$ toxicity over the control at 250 and $500 \mu \mathrm{g} / \mathrm{ml}$ concentrations. Zymography demonstrated MMP-2 and MMP-9 secretion which was inhibited by NM in a dose-dependent manner, with virtual total inhibition of both at $1,000 \mu \mathrm{g} / \mathrm{ml}$. Migration by scratch test and invasion through Matrigel were inhibited in a dose-dependent manner with total block of invasion at 250 and of migration at $1,000 \mu \mathrm{g} / \mathrm{ml}$. These results suggest that NM has therapeutic potential in the treatment of breast cancer.
\end{abstract}

Correspondence to: Dr Aleksandra Niedzwiecki, Dr. Rath Research Institute, 1260 Memorex Drive, Santa Clara, CA 95050, USA

E-mail: author@drrath.com

Key words: breast cancer 4T1 cell line, nutrients, tumor growth, metastasis, MMPs, migration, Matrigel invasion

\section{Introduction}

Breast cancer, the most prevalent cancer in women worldwide and the leading cause of cancer death in women, was projected to claim the lives of $\sim 39,620$ women in the USA in 2013 (1). Though treatable in early stages, once metastasis has occurred, the survival rate is drastically reduced to a median of 2-3 years and treatment focuses on palliative care (2).

Critical events in tumor cell invasion include cell attachment, proteolytic degradation of the extracellular matrix (ECM) and migration through the disrupted matrix (3). Rath and Pauling (4) proposed that nutrients such as lysine and ascorbic acid could act as natural inhibitors of ECM degradation, inhibiting MMP activity and strengthening the connective tissue surrounding cancer cells, and thus potentially modulating tumor growth and expansion. We have developed strategies to inhibit cancer development and its spread using naturally occurring nutrients such as lysine, proline, ascorbic acid and green tea extract (NM). This nutrient mixture has exhibited synergistic anticancer activity in vivo and in vitro in a number of cancer cell lines through inhibition of cancer cell growth, MMP secretion, invasion, metastasis and angiogenesis (5).

A major problem in studying metastasis has been the lack of suitable models that faithfully represent the metastatic process as it occurs in vivo. While some human xenograft models can approximate primary tumor growth in mice, replication of tumor metastasis is more problematic (6-8). Generally, human tumor cells metastasize poorly in mice and metastases are associated with unexpected characteristics. In contrast, murine tumor cell models often metastasize more effectively and display metastatic characteristics more similar to those observed in cancer patients (9). Since microenvironments and tumor-host interactions play important roles in tumor cell behavior, this is not surprising. When introduced orthoptopically, 4T1 is capable of metastasis to several organs affected in breast cancer, including lungs, liver and brain as well as bone.

In this study, our main objective was to determine the effect of dietary supplementation with NM on the development of tumors and metastasis to other organs challenging mice with breast cancer 4T1 cells into the mammary pad. The 4T1 mammary carcinoma model was chosen as it has several characteristics that make it a suitable experimental animal model for human mammary cancer growth and metastasis $(10,11)$. The tumor cells are easily transplanted into the mammary gland so that the primary tumor grows in 
the anatomically correct site and, as in human breast cancer, 4T1 metastatic disease develops spontaneously from the primary tumor. In addition, metastatic spread of 4T1 metastases to other organs and the draining lymph nodes is similar to that of human mammary cancer (10). In addition, we studied the effect of NM on 4T1 cells in vitro evaluating viability, MMP secretion, migration and invasion.

\section{Materials and methods}

Cancer cell line and culture. Murine breast cancer cell line 4T1 was obtained from ATCC (American Type Culture Collection, Rockville, MD, USA). 4T1 cells were maintained in DMEM, supplemented with $10 \%$ fetal bovine serum, $100 \mathrm{U} / \mathrm{ml}$ penicillin and $100 \mu \mathrm{g} / \mathrm{ml}$ streptomycin. The media and sera used were obtained from ATCC, and antibiotics (penicillin and streptomycin) were from Gibco BRL (Long Island, NY, USA).

Composition of the nutrient mixture. The nutrient mixture (NM) was composed of the following in the ratio indicated: vitamin $\mathrm{C}$ (as ascorbic acid and as $\mathrm{Mg}, \mathrm{Ca}$ and palmitate ascorbate) $700 \mathrm{mg}$; L-lysine 1,000 mg; L-proline $750 \mathrm{mg}$; L-arginine $500 \mathrm{mg}$; N-acetyl cysteine $200 \mathrm{mg}$; standardized green tea extract [derived from green tea leaves, was obtained from US Pharma Lab; the certificate of analysis indicated the following characteristics: total polyphenol $80 \%$, catechins $60 \%$, epigallocatechin gallate (EGCG) $35 \%$ and caffeine $1.0 \%$ ]; $1,000 \mathrm{mg}$; selenium $30 \mu \mathrm{g}$; copper $2 \mathrm{mg}$; manganese $1 \mathrm{mg}$.

\section{In vivo studies}

Animals. Female Balb/C mice, approximately five weeks of age on arrival, were purchased from Simonsen Laboratories (Gilroy, CA, USA) and maintained in microisolator cages under pathogen-free conditions on a 12-h light/12-h dark schedule for a week. All procedures were performed according to humane and customary care and use of experimental animals and followed a protocol approved by internal institutional animal safety review committee.

Experimental design. After housing for a week, the mice $(n=14)$ were inoculated with $5 \times 10^{5} 4 \mathrm{~T} 1$ cells in $0.2 \mathrm{ml}$ PBS and $0.1 \mathrm{ml}$ Matrigel (BD Bioscience, Bedford, MA, USA) into the mammary pad. After injection, the mice were randomly divided into two groups and maintained for four weeks on the following diets; the control group mice were fed regular Purina mouse chow and the NM group the regular diet supplemented with $0.5 \% \mathrm{NM}(\mathrm{w} / \mathrm{w})$. During the study, the mice consumed, on the average, $4 \mathrm{~g}$ of their respective diets per day. Thus, the supplemented mice received $20 \mathrm{mg}$ of NM per day. After four weeks, the mice were sacrificed and their tumors, lungs, livers, kidneys, hearts and spleens were excised and processed for histology. Dimensions (length and width) of tumors were measured using a digital caliper, and the tumor burden was calculated using the following formula: $0.5 \mathrm{x}$ length $\mathrm{x}$ width. Mean weight of mice at initiation of study and termination of study did not differ significantly between the groups.

Histology. Tissue samples were fixed in $10 \%$ buffered formalin and sent to IDEXX Reference Laboratories for processing, blocking, sectioning and staining with hematoxylin and eosin
(H\&E). Tumors and organs from mice were evaluated using a standard light microscope.

\section{In vitro studies}

Cell culture. Murine breast 4T1 cells were grown in DMEM, supplemented with $10 \%$ fetal bovine serum, penicillin $(100 \mathrm{U} / \mathrm{ml})$ and streptomycin $(100 \mathrm{mg} / \mathrm{ml})$ in 24 -well tissue culture plates (Costar, Cambridge, MA, USA). Cells were incubated with $1 \mathrm{ml}$ of media at $37^{\circ} \mathrm{C}$ in a tissue culture incubator equilibrated with $95 \%$ air and $5 \% \mathrm{CO}_{2}$. At near confluence, the cells were treated with the nutrient mixture, dissolved in media and tested at $0,10,50,100,500$ and 1,000 $\mu \mathrm{g} / \mathrm{ml}$ in triplicate at each dose. Phorbol 12-myristate 13-acetate (PMA), $100 \mathrm{ng} / \mathrm{ml}$, was added to cells to induce MMP-9 secretion. The plates were then returned to the incubator.

MTT assay. Cell viability was evaluated by MTT assay, a colorimetric assay based on the ability of viable cells to reduce a soluble yellow tetrazolium salt [3-(4,5-dimethylthiazol-2-yl) 2,5-diphenyl tetrazolium bromide] (MTT) to a blue formazan crystal by mitochondrial succinate dehydrogenase activity of viable cells. This test is a good index of mitochondrial activity and thus of cell viability. After 24-h incubation, the cells were washed with phosphate-buffered saline (PBS) and $500 \mu \mathrm{l}$ of MTT (Sigma no. M-2128) $0.5 \mathrm{mg} / \mathrm{ml}$ in media was added to each well. After MTT addition $(0.5 \mathrm{mg} / \mathrm{ml})$ the plates were covered and returned to the $37^{\circ} \mathrm{C}$ incubator for $2 \mathrm{~h}$, the optimal time for formazan product formation. Following incubation, the supernatant was carefully removed from the wells, the formazan product was dissolved in $1 \mathrm{ml}$ DMSO and absorbance was measured at $570 \mathrm{~nm}$ in Bio Spec 1601, Shimadzu spectrometer. The $\mathrm{OD}_{570}$ of the DMSO solution in each well was considered to be proportional to the number of cells. The $\mathrm{OD}_{570}$ of the control (treatment without supplement) was considered $100 \%$.

Gelatinase zymography. Gelatinase zymography was performed in $10 \%$ Novex Pre-Cast SDS polyacrylamide gel (Invitrogen Corp.) in the presence of $0.1 \%$ gelatin under non-reducing conditions. Culture media $(20 \mu \mathrm{l})$ were mixed with sample buffer and loaded for SDS-PAGE with tris glycine SDS buffer, as suggested by the manufacturer (Novex). Samples were not boiled before electrophoresis. Following electrophoresis the gels were washed twice in $2.5 \%$ Triton X-100 for $30 \mathrm{~min}$ at room temperature to remove SDS. The gels were then incubated at $37^{\circ} \mathrm{C}$ overnight in substrate buffer containing $50 \mathrm{mM}$ Tris- $\mathrm{HCl}$ and $10 \mathrm{mM} \mathrm{CaCl}_{2}$ at $\mathrm{pH} 8.0$ and stained with $0.5 \%$ Coomassie Blue R250 in 50\% methanol and $10 \%$ glacial acetic acid for $30 \mathrm{~min}$ and destained. Upon renaturation of the enzyme, the gelatinases digested the gelatin in the gel, producing clear bands against an intensely stained background. Protein standards were run concurrently and approximate molecular weights were determined by plotting the relative mobilities of known proteins.

Migration: scratch test. To study cell migration, a 2-mm wide single uninterrupted scratch was made from top to bottom of culture plates of cancer cells grown to confluence. Culture plates were washed with PBS and incubated with NM in medium and tested at $0,50,100,250,500$ and $1,000 \mu \mathrm{g} / \mathrm{ml}$ in 

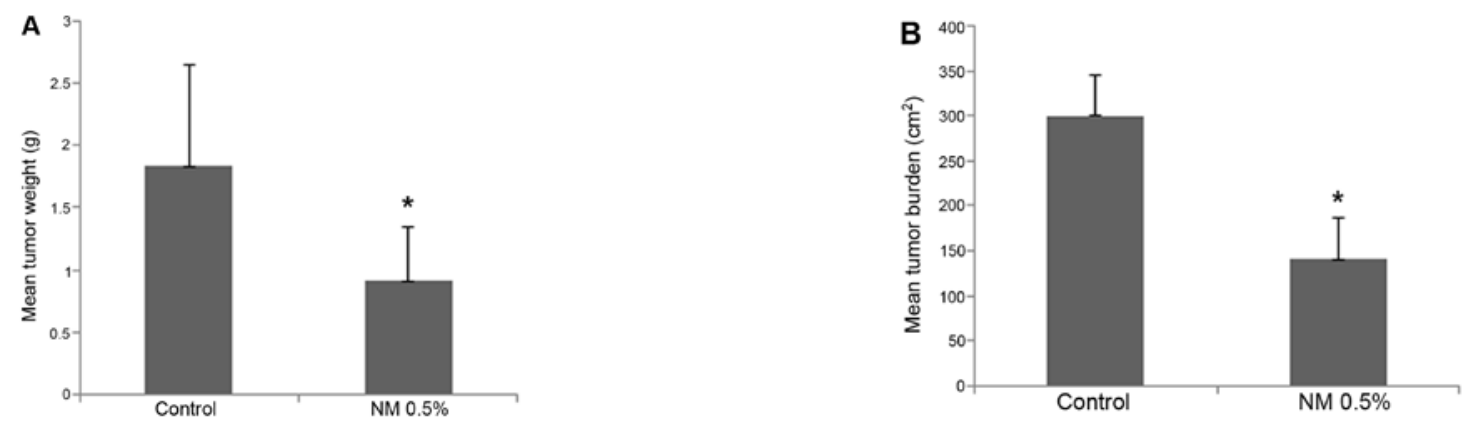

Figure 1. Effect of NM 0.5\% supplementation on 4T1 tumor growth in Balb/C mice. (A) Mean tumor weight; (B) mean tumor burden (the asterisk indicates significance of $\mathrm{p}<0.05$ with respect to control).
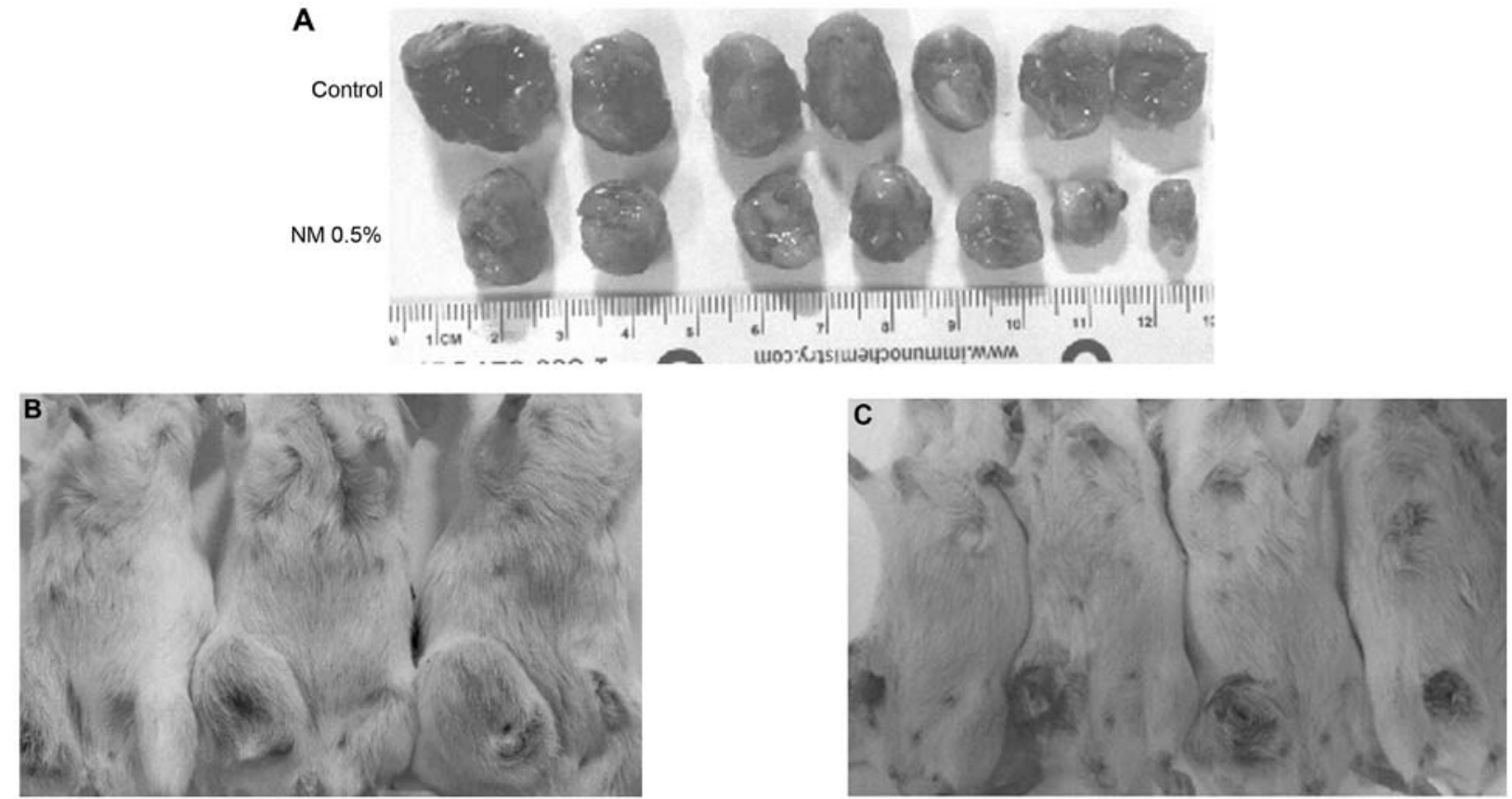

Figure 2. (A) Gross tumor images of control and NM 0.5\% group tumors; (B) mice from control group; (C) mice from NM 0.5\% group.

triplicate at each dose for $24 \mathrm{~h}$. Cells were washed with PBS, fixed and stained with $H \& E$ and photomicrographs were taken.

Matrigel invasion. Invasion studies were conducted using Matrigel (Becton-Dickinson) inserts in 24-well plates. Suspended in medium, 4T1 cells were supplemented with nutrients, as specified in the design of the experiment, and seeded on the insert in the well. Thus both the medium on the insert and in the well contained the same supplements. The plates with the inserts were then incubated in a culture incubator equilibrated with $95 \%$ air and $5 \% \mathrm{CO}_{2}$ for $24 \mathrm{~h}$. After incubation, the media from the wells were withdrawn. The cells on the upper surface of the inserts were gently scrubbed away with cotton swabs. The cells that had penetrated the Matrigel membrane and migrated onto the lower surface of the Matrigel were stained with hematoxylin and eosin and visually counted under a microscope.

Morphology. Morphology of cells cultured for $24 \mathrm{~h}$ in test concentrations of NM were evaluated by H\&E staining and observed and photographed by microscopy.
Statistical analysis. The results are expressed as means \pm SD, as indicated in the results, for the groups. Data was analyzed by independent sample ' $t$ '-test.

\section{Results}

In vivo studies

Tumor weight and burden. NM strongly inhibited tumor growth and burden of 4T1 tumors in female Balb/C mice. Mean tumor weight was inhibited by $50 \%(\mathrm{p}=0.02)$ with NM $0.5 \%$ dietary supplementation, as shown in Fig. 1A and tumor burden was inhibited by $53.4 \%$ (p $\leq 0.0001)$, as shown in Fig. 1B. Mean tumor weight of supplemented mice was $0.91 \pm 0.43 \mathrm{~g}$ and that of mice on the control diet $1.83 \pm 0.81 \mathrm{~g}$. Mean tumor burden of supplemented mice was $140 \pm 48 \mathrm{~cm}^{2}$ and that of mice on the control diet $300 \pm 45 \mathrm{~cm}^{2}$. Images of mice and gross tumors from groups are shown in Fig. 2.

Tumor histopathology. Histologically, both groups demonstrated irregularly round subcutaneous tumors with large central areas of tumor necrosis involving $70 \%$ of the tumor 

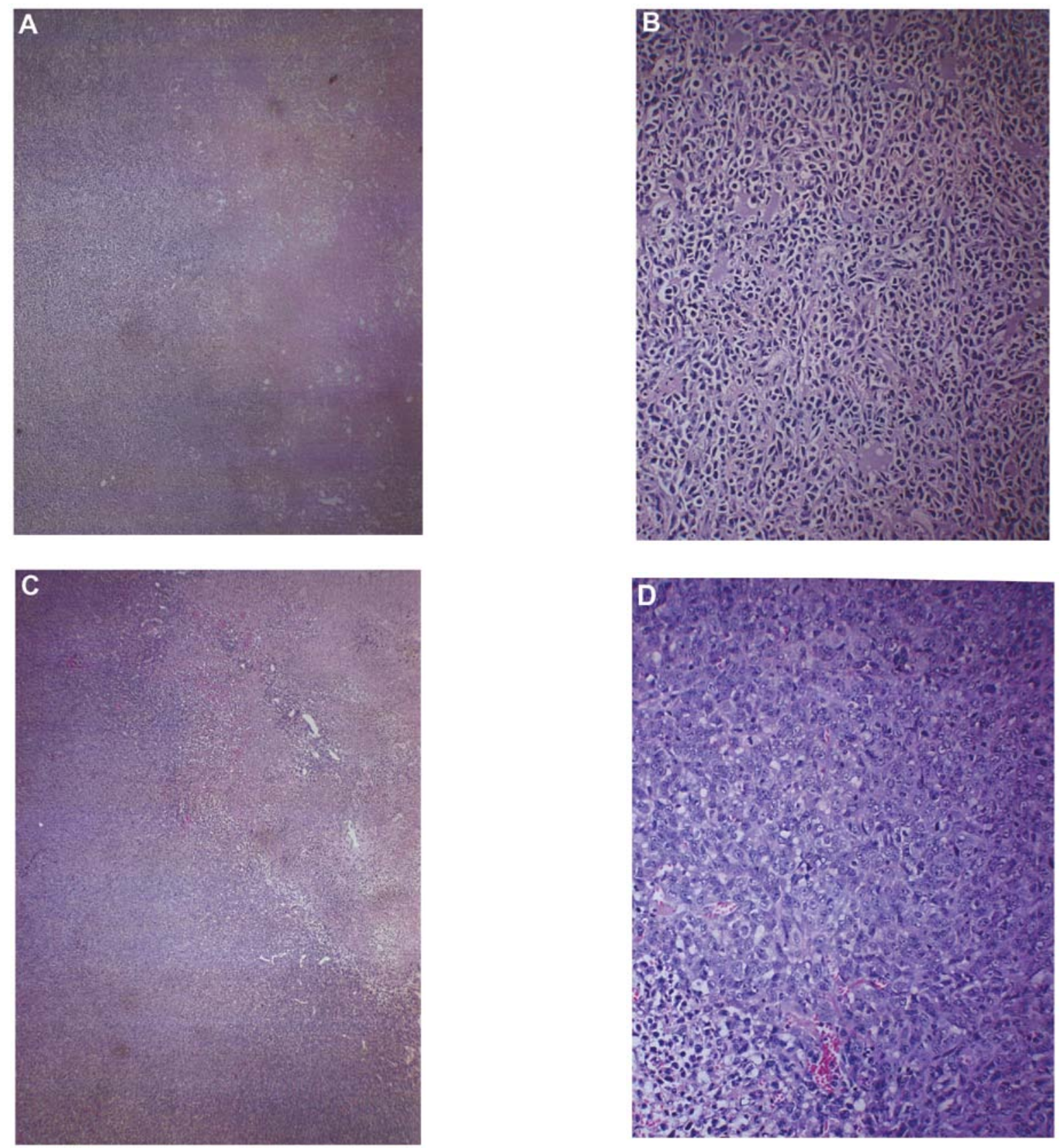

Figure 3. Tumor histopathology. (A) Control tumor, x40; (B) control tumor, x200; (C) NM 0.5\% tumor, x40; (D) NM 0.5\% tumor, x200.
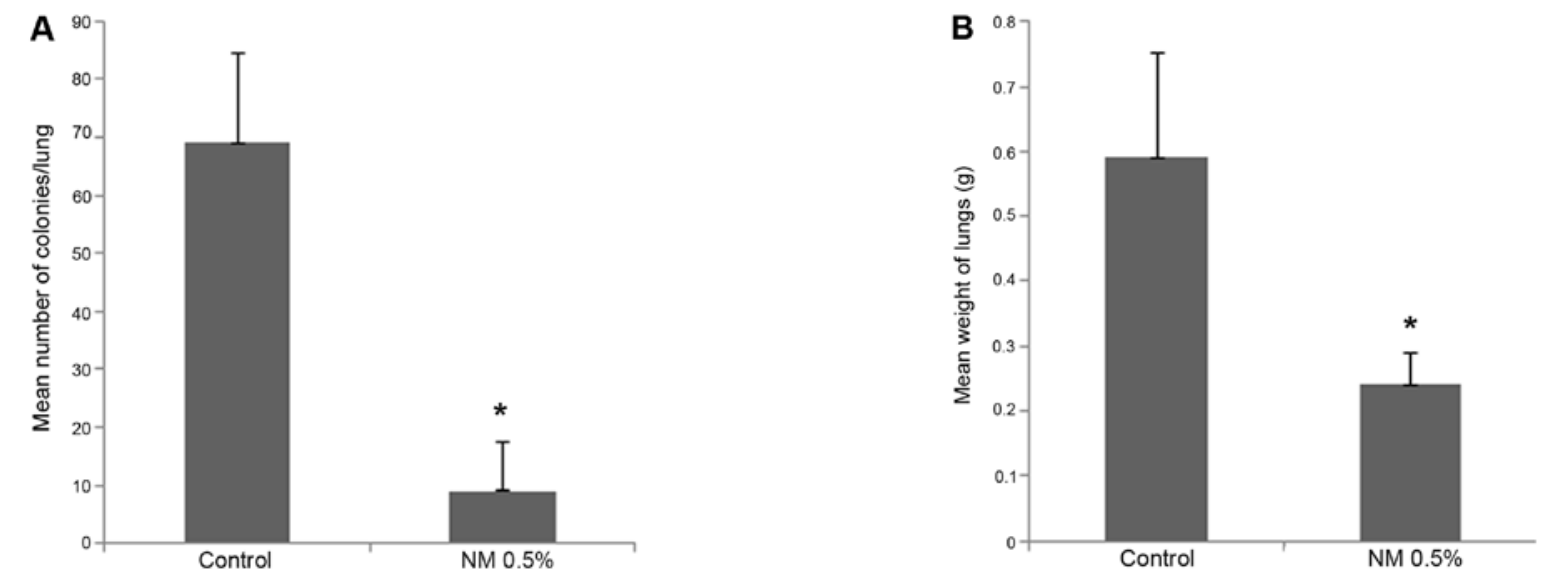

Figure 4. Lung metastasis. (A) Mean number of colonies in lungs of control and NM 0.5\% group; (B) comparative weights of lungs in control and NM 0.5\% group (the asterisk indicates significance of $\mathrm{p}=0.0001$ with respect to control). 


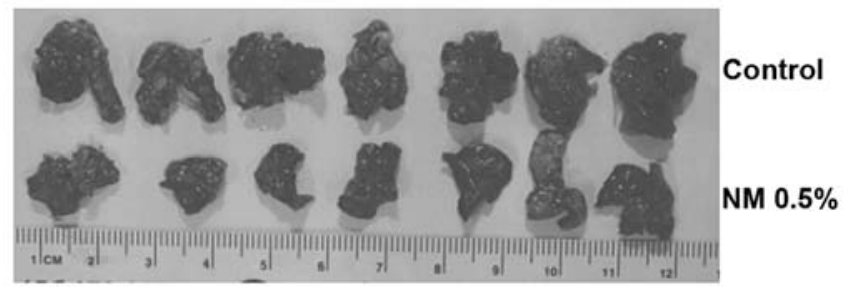

Figure 5. Gross lung images of mice on control and NM supplemented diets.

mass in the control mice and $50-70 \%$ in the supplemented mice. Viable, peripheral tumor tissue consisted of sheaths of small irregularly-round to spindle-shaped cells with poorly defined cytoplasm and often vesiculated nuclei. Mitotic figures averaged 1-2 per high-power field (Fig. 3).

Metastasis to lungs. Mice supplemented with NM $0.5 \%$ showed profoundly reduced number of colonies in the lungs as contrasted to the lungs of control mice. Mean number of colonies in the lungs of supplemented mice $(9 \pm 8.4)$ were $13 \%$ $(\mathrm{p}<0.0001)$ of the mean number of colonies in the lungs of control mice $(69 \pm 15.6)$, as shown in Fig. 4A. Furthermore, mean weight of lungs of supplemented mice $(0.24 \pm 0.05 \mathrm{~g})$ were $40.7 \%(p=0.0001)$ of the mean weight of lungs of control mice $(0.59 \pm 0.16 \mathrm{~g})$, as shown in Fig. 4B. Images of gross lungs from groups are shown in Fig. 5.

Lung histopathology. Multiple metastases were observed in the lungs of control mice in contrast to few, small metastatic lesions in lungs of NM supplemented mice. Neoplastic cells

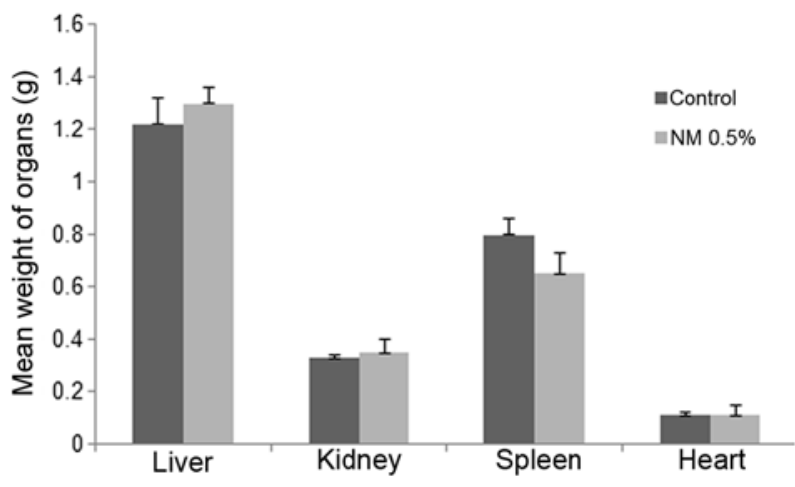

Figure 7. Mean weights of livers, kidneys, spleens and hearts in control and NM groups.

were large, irregularly round, with prominent large, irregularly round nuclei and scant cytoplasm (Fig. 6).

Mean weights of livers, kidneys, spleens and hearts. No significant differences were found between control and NM supplemented mean organ weights, as shown in Fig. 7.

Metastasis to liver. Two of three liver sections examined from control group livers showed 2-3 small, metastatic lesions associated with severe, perivascular and sinusoidal neutrophilic infiltration. The third section had no evidence of metastasis or severe neutrophilic infiltration, but did have multifocal areas of severe, acute liver necrosis. All four sections of liver examined in NM $0.5 \%$ fed mice, showed no definite metastatic lesions. Many vessels were severely cuffed with neutrophils. A
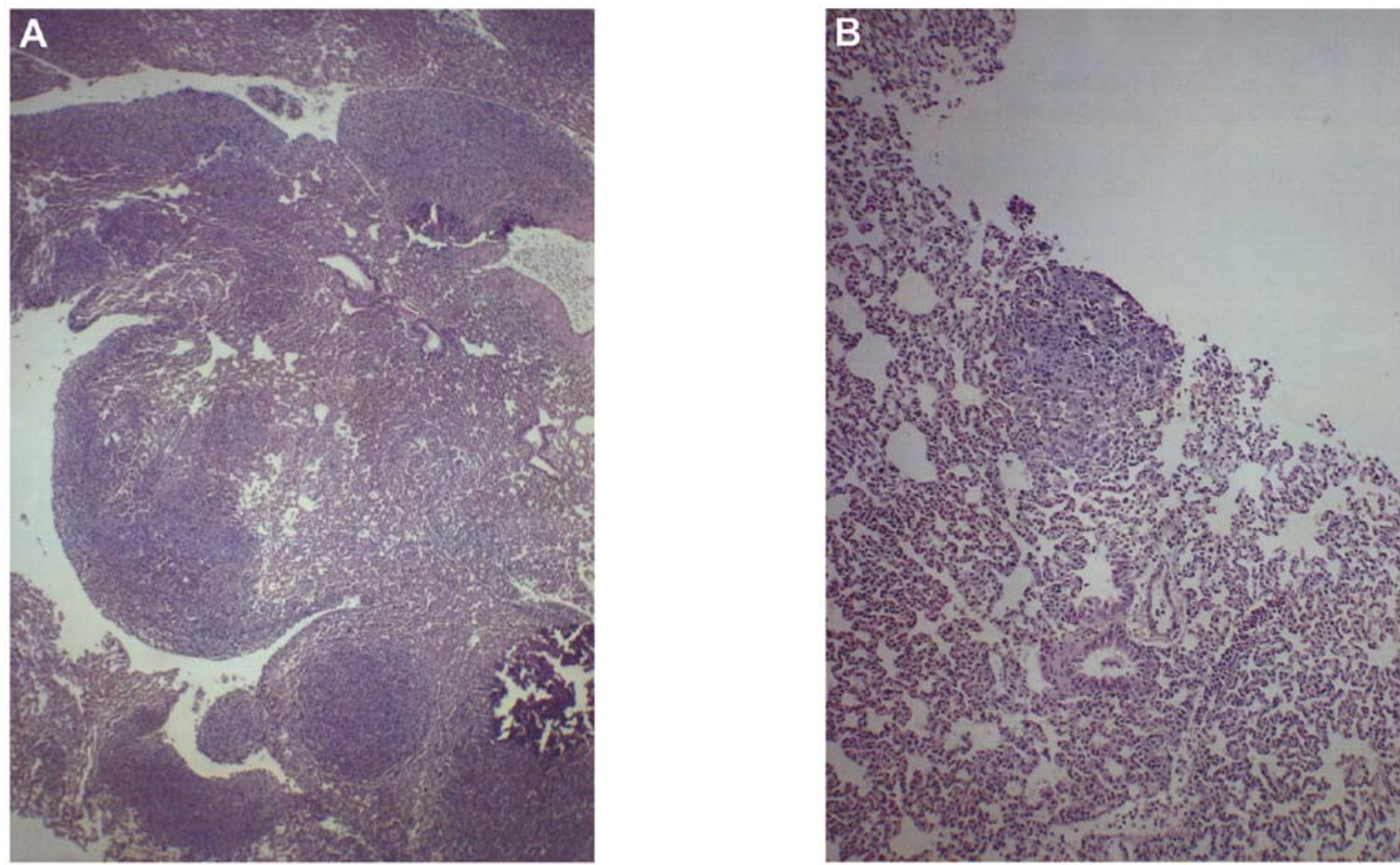

Figure 6. Lung histopathology. (A) Lung control, x40; (B) lung NM 0.5\%, x100. 


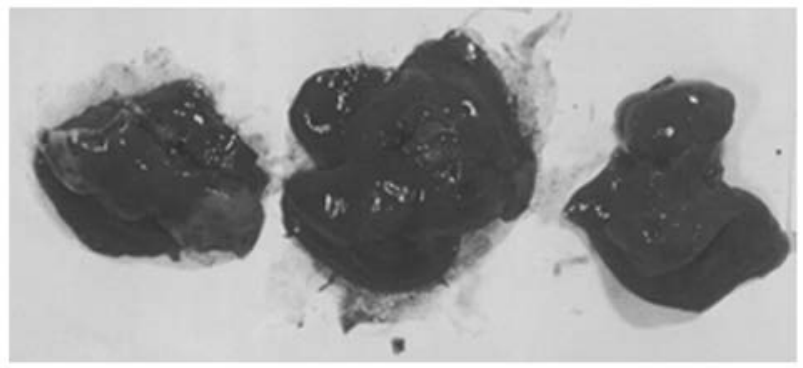

Figure 8. Gross images of control group livers.

few questionable cells presented in sinusoids, but these most likely were myeloid in origin. Gross images of control livers are shown in Fig. 8 and histopathology of livers from control and supplemented mice is shown in Fig. 9.

Metastasis to kidney. Three partial kidney sections of control mice presented subscapsular, metastatic lesions and one section areas of acute infarction. Of three sections of NM kidney examined, no metastases or specific changes were noted. Gross images of control kidneys are shown in Fig. 10 and histopathology of kidneys from control and supplemented mice is shown in Fig. 11.

Metastasis to heart. Among the control group heart sections examined, four of five showed myocardial metastatic lesions, one large and three smaller metastases. In the NM heart sections examined, two of four sections each had a metastatic lesion near the base of the heart. Gross images of hearts from

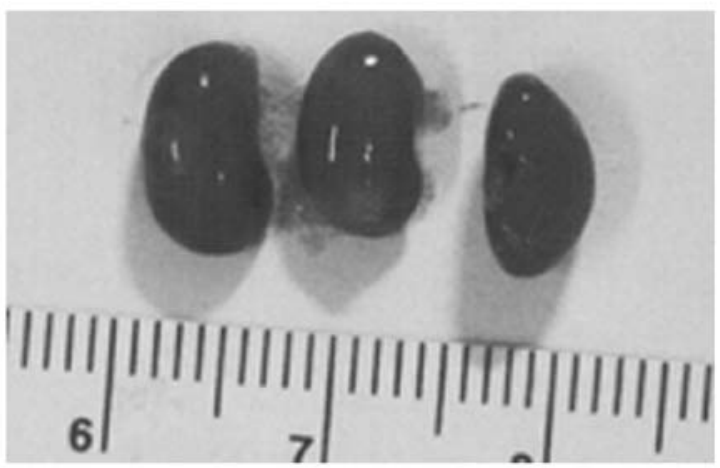

Figure 10. Gross images of control group kidneys.

both groups are shown in Fig. 12 and histopathology of hearts from control and supplemented mice is shown in Fig. 13.

Metastasis to spleen. Of the three sections of control group spleens examined, all showed severe, extramedullary hematopoiesis and 2-3 small metastases. Sections of NM spleen showed severe, extramedullary hematopoietic activity and a small, metastatic lesion in one section. Gross images of control spleens are shown in Fig. 14 and histopathology of spleens from control and supplemented mice is shown in Fig. 15.

\section{In vitro}

Cell proliferation: MTT assay. NM exhibited dose-dependent inhibition of $4 \mathrm{~T} 1$ cell growth with $50 \%(\mathrm{p}<0.0001)$ antiproliferative effect at 250 and $500 \mu \mathrm{g} / \mathrm{ml}$ and $60 \%(\mathrm{p}<0.0001)$ at $1,000 \mu \mathrm{g} / \mathrm{ml}$ compared to control, as shown in Fig. 16.
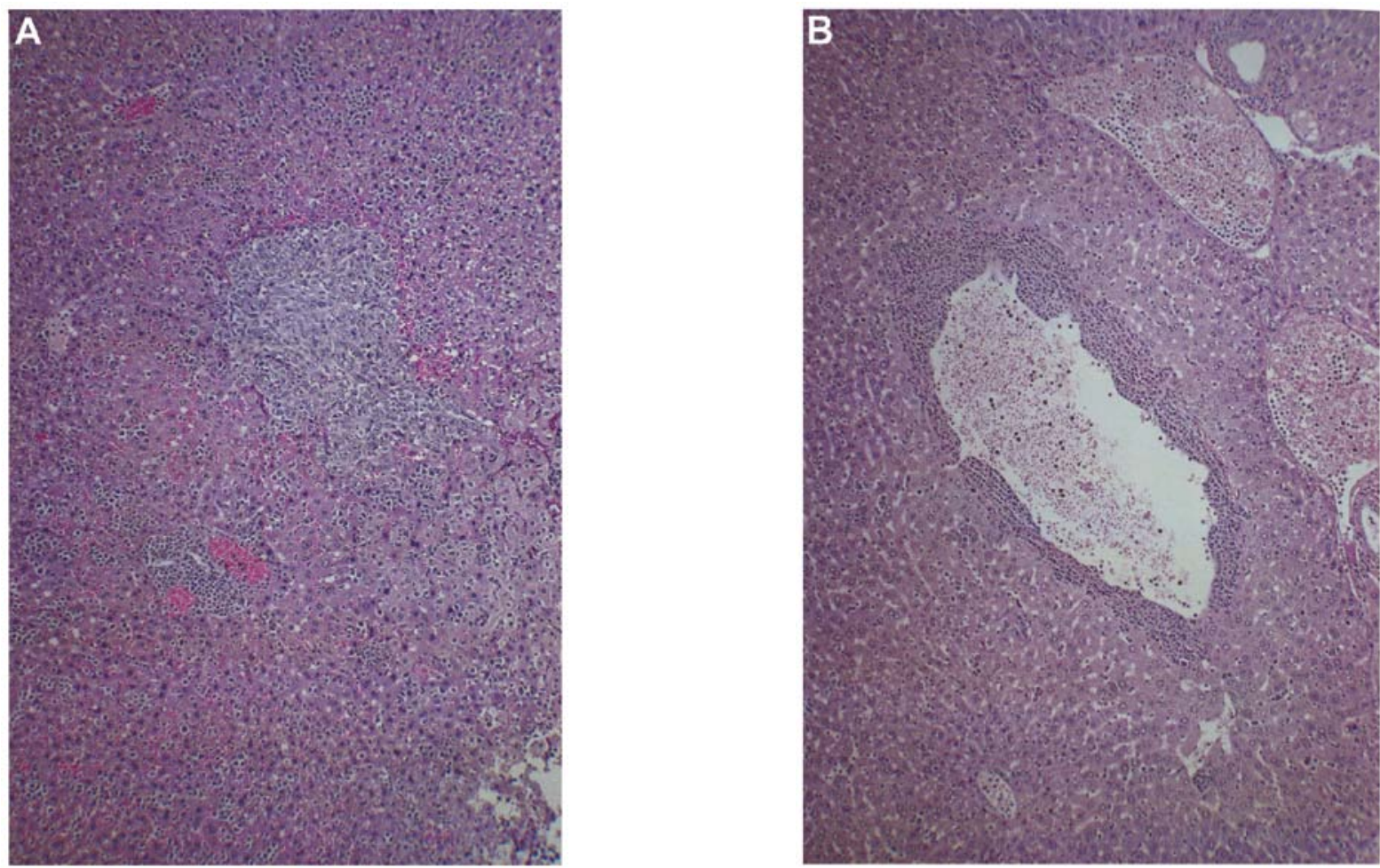

Figure 9. Histopathology of livers. (A) Liver control, x100; (B) liver NM 0.5\%, x100. 

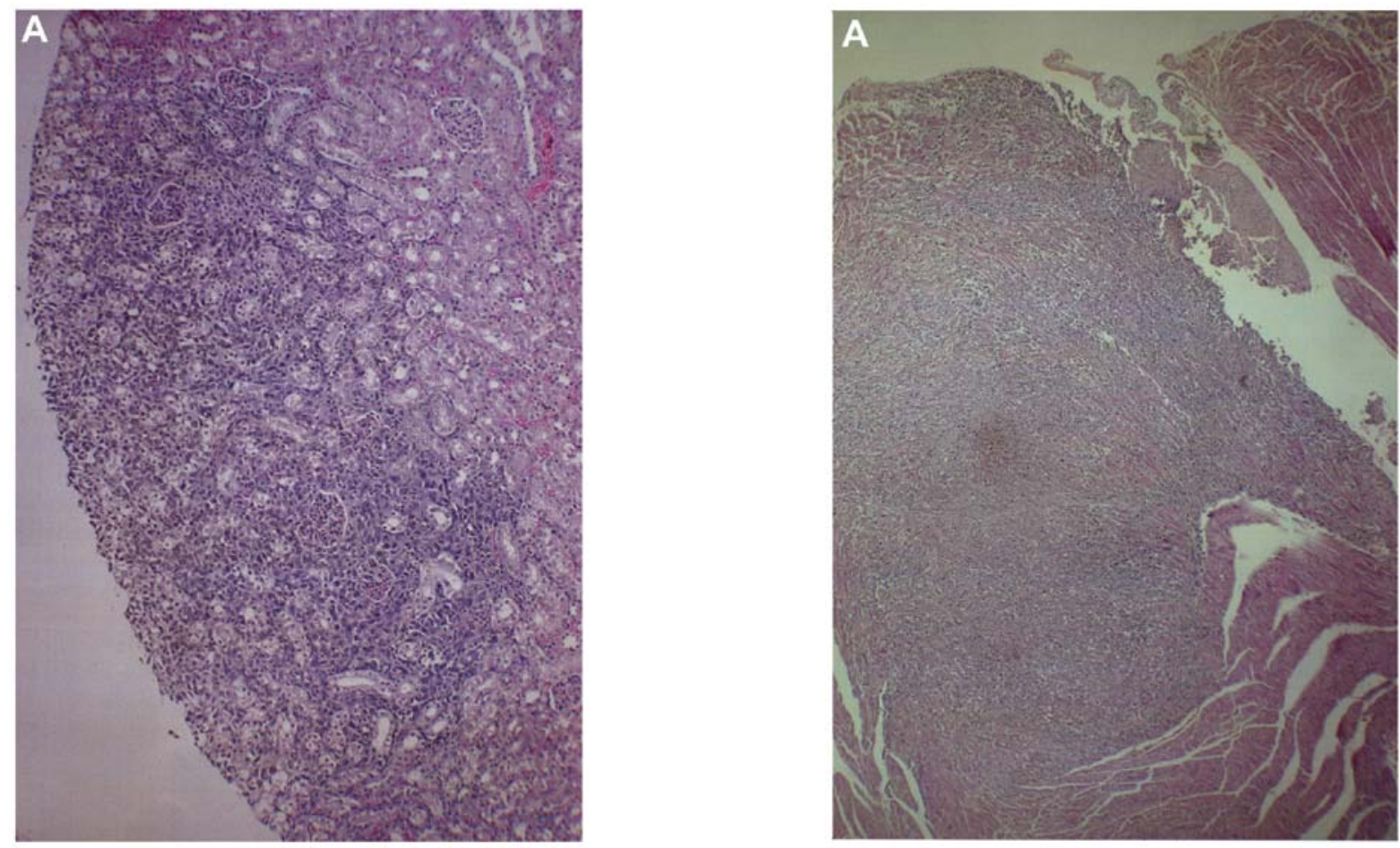

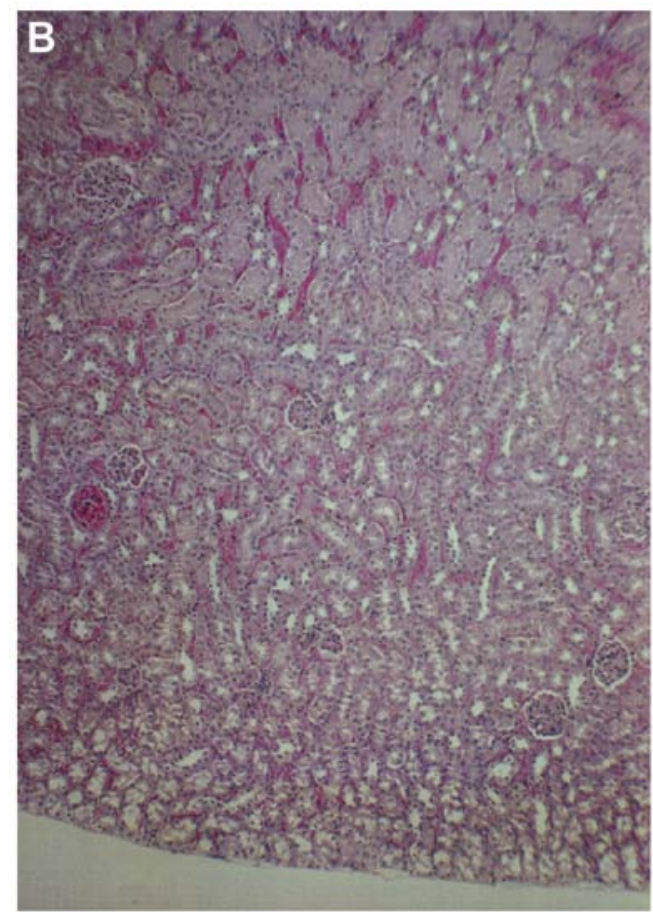

Figure 11. Histopathology of kidneys. (A) Kidney control, x100; (B) kidney NM $0.5 \%, x 100$.

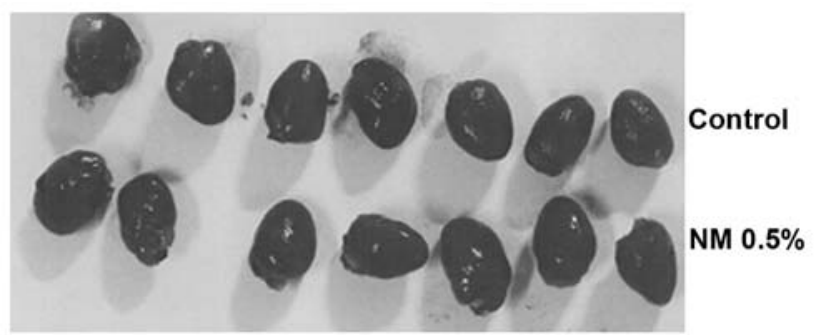

Figure 12. Gross images of hearts.

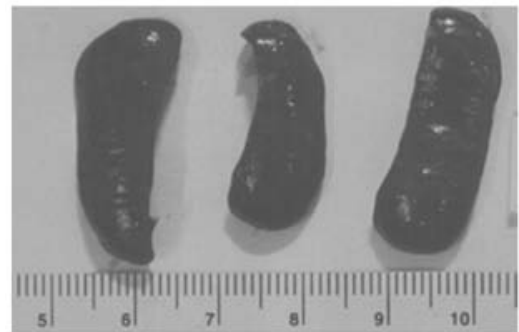

Figure 14. Gross images of control spleen. 

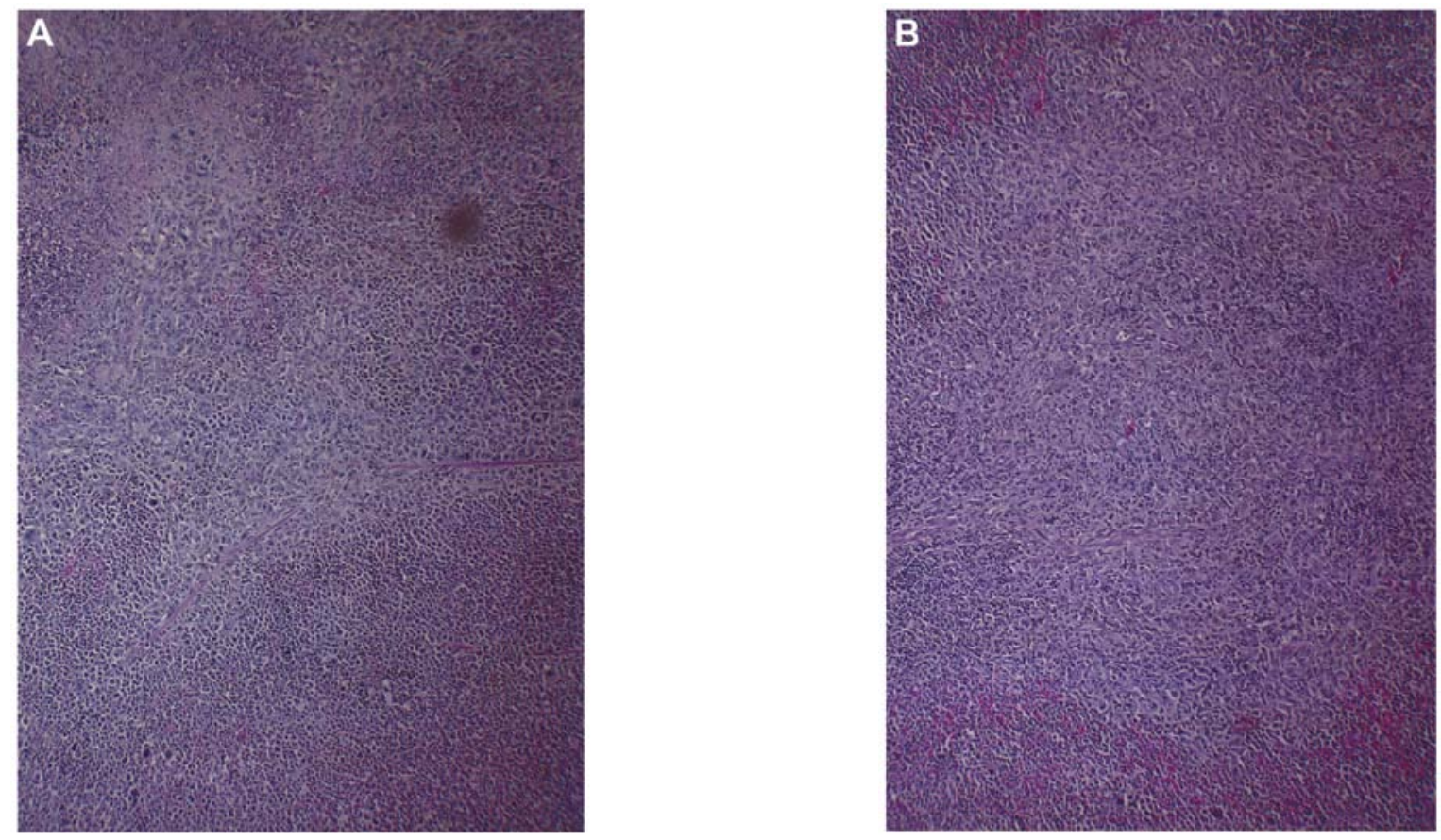

Figure 15. Histopathology of spleen. (A) Control spleen, x100; (B) NM spleen, x100.

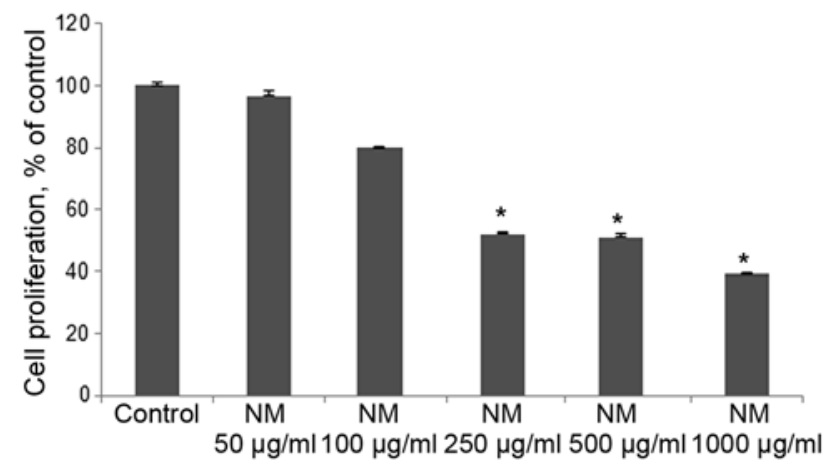

Figure 16. Effect of NM on 4T1 cell proliferation - MTT 24-h assay (the asterisk indicates significance of $\mathrm{p}<0.0001$ with respect to control).

Gelatinase zymography. Zymography demonstrated MMP-2 and MMP-9 secretion by untreated and PMA-treated 4T1 cells . NM inhibited secretion of both MMPs in a dose-dependent manner with virtual total inhibition of both at $1,000 \mu \mathrm{g} / \mathrm{ml}$, as shown in Fig. 17.

Migration: scratch test. NM reduced breast cancer 4T1 cell migration in a dose-dependent manner, with total inhibition at $1,000 \mu \mathrm{g} / \mathrm{ml}$, as shown in Fig. 18.
Matrigel invasion. NM significantly inhibited 4T1 invasion through Matrigel in a dose-dependent manner, with total block at $250 \mu \mathrm{g} / \mathrm{ml}$, as shown in Fig. 19.

Morphology: H\&E staining. H\&E staining showed no morphological changes even at higher concentrations of NM, as shown in Fig. 20.

\section{Discussion}

The results of the in vivo study of murine $4 \mathrm{~T} 1$ cells injected into the mammary pads of Balb/C mice demonstrated significant suppression of tumor growth $(50 \%$ reduction in tumor weight and 53\% in tumor burden) with NM dietary supplementation. Lung metastasis was profoundly inhibited by NM supplementation: mean number of colonies was reduced by $87 \%$ and mean weight of lungs by $60 \%$ compared to control mice. Metastasis to liver, spleen, kidney and heart was significantly reduced with NM supplementation. The results from the in vitro studies support the in vivo findings. In vitro, NM inhibited cell proliferation by $50 \%$ at 250 and $500 \mu \mathrm{g} / \mathrm{ml}$ concentrations compared to the control. Zymography demonstrated MMP-2 and MMP-9 secretion which was inhibited by NM in a dose-dependent manner, with virtual total inhibition

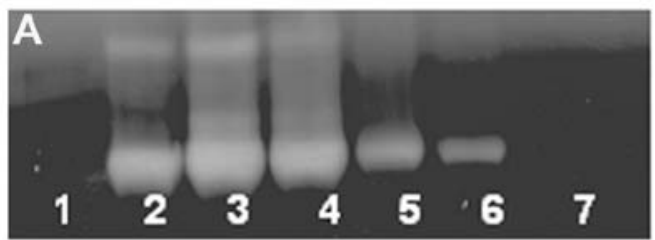

MMP-9

MMP-2

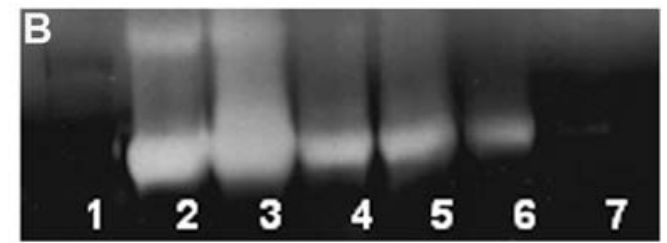

Figure 17. Effect of NM on MMP-2 and MMP-9 secretion by 4T1 cells: gelatinase zymography. (A) Untreated 4T1 cells; (B) PMA-treated 4T1 cells. 

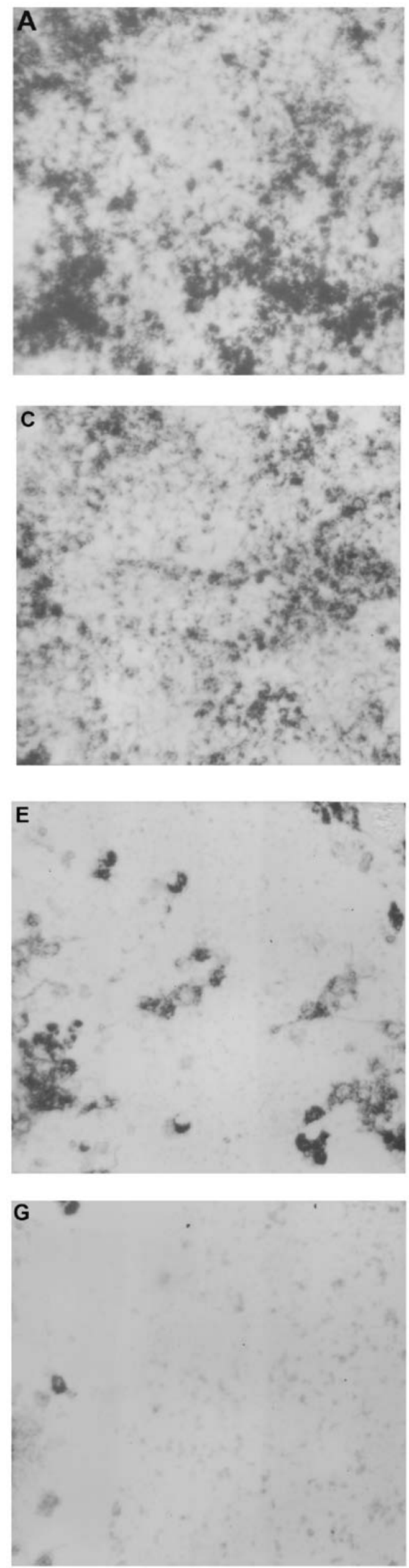
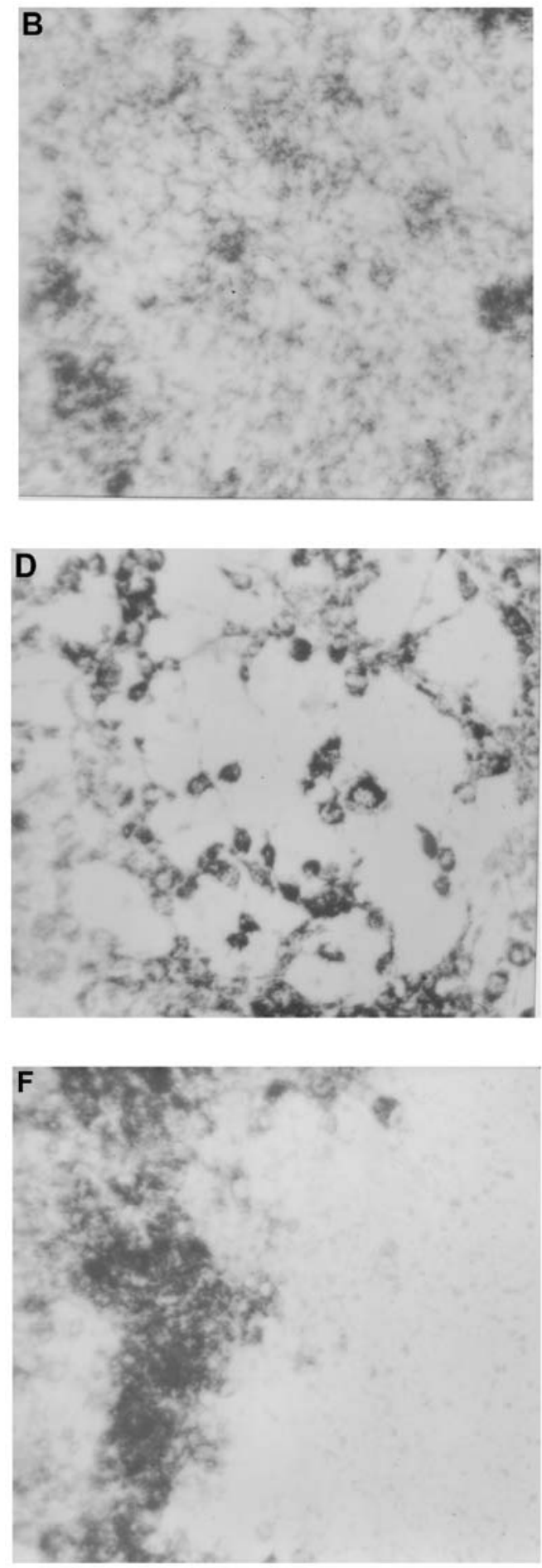

Figure 18. Effect of NM on 4T1 cell migration: scratch test. (A) Pre-scratch; (B) control $24 \mathrm{~h}$; (C) NM $50 \mu \mathrm{g} / \mathrm{ml} 24 \mathrm{~h}$; (D) NM $100 \mu \mathrm{g} / \mathrm{ml} 24 \mathrm{~h}$; (E) NM $250 \mu \mathrm{g} / \mathrm{ml} 24 \mathrm{~h}$; (F) NM $500 \mu \mathrm{g} / \mathrm{ml} 24 \mathrm{~h}$; (G) NM 1,000 $\mu \mathrm{g} / \mathrm{ml} 24 \mathrm{~h}$.

of both at $1,000 \mu \mathrm{g} / \mathrm{ml}$. Migration by scratch test and invasion through Matrigel were inhibited dose-dependently with total block of invasion at 250 and of migration at $1,000 \mu \mathrm{g} / \mathrm{ml}$.

Tao et al reported that metastasis of 4T1 tumors was associated with extensive necrosis and inflammation within the primary tumor and hematopoiesis in several mouse organs including spleen and liver (10). In our study, both groups demonstrated irregularly round subcutaneous tumors with large central areas of tumor necrosis involving $70 \%$ of the 

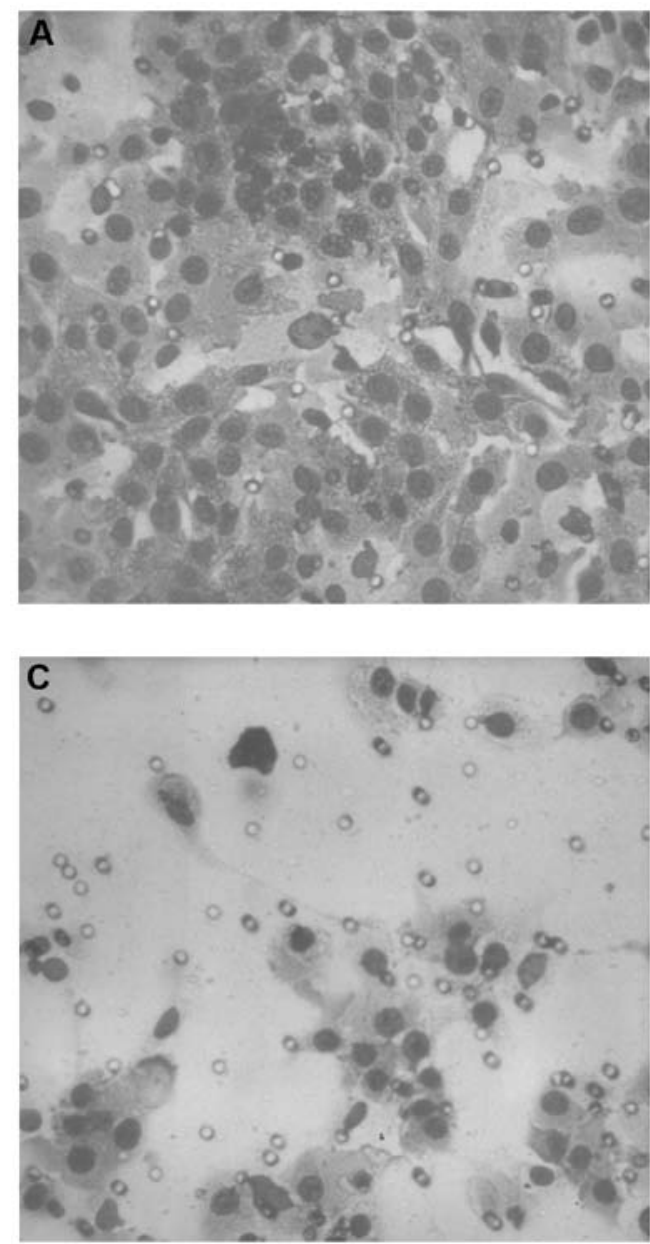
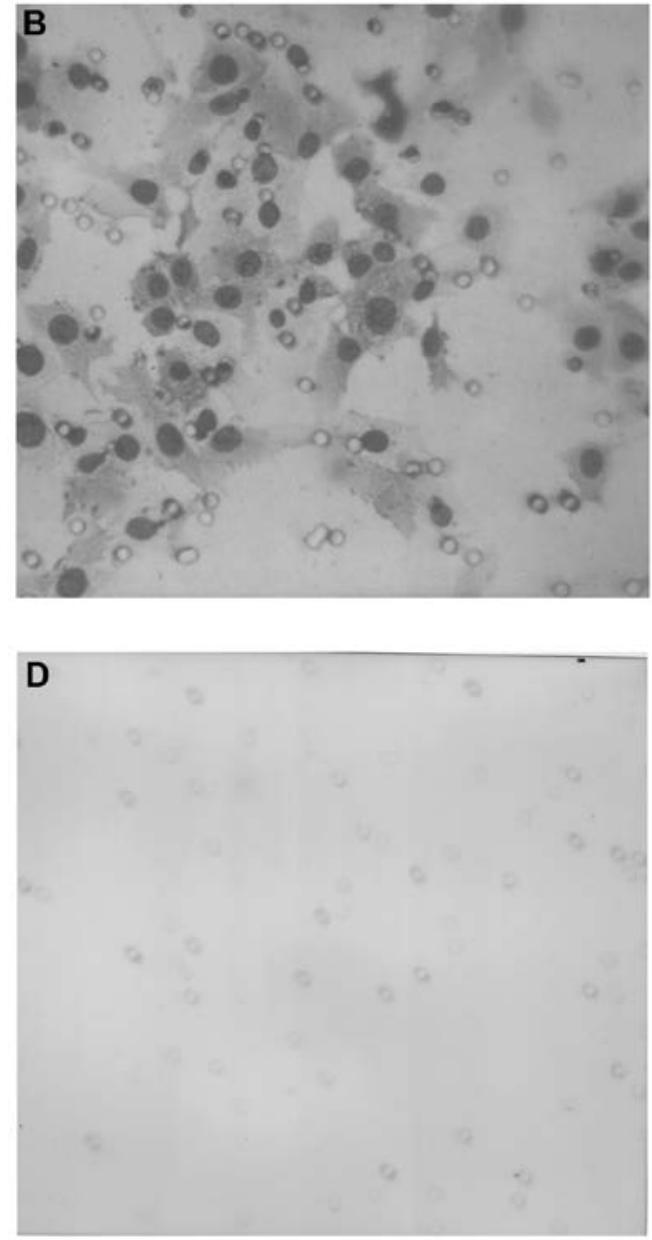

Figure 19. Effect of NM on 4T1 cell invasion through Matrigel; photomicrographs. (A) Control; (B) NM $50 \mu \mathrm{g} / \mathrm{ml}$; (C) NM $100 \mu \mathrm{g} / \mathrm{ml}$; (D) NM $250 \mu \mathrm{g} / \mathrm{ml}$.

tumor mass in the control mice and 50-70\% in the supplemented mice. As discussed earlier, we observed multiple metastases in the lungs of control mice in contrast to few small metastatic lesions in lungs of NM supplemented mice. Splenic metastasis showed severe, extramedullary hematopoiesis and 2-3 small metastases in the spleen sections of control mice and a small metastatic lesion and extramedullary hematopoietic activity in the sections of supplemented mice. Liver metastasis in our study showed several small metastatic lesions associated with severe, perivascular and sinusoidal neutrophilic infiltration in the control sections and absence of metastatic lesions but presence of neutrophils in supplemented sections.

Bonfil et al reported that the distribution of necrosis within a primary tumor was responsible in part for the development of metastases (12), and that tumor necrosis was an important source of gelatinase/type IV collagenase, mainly in its $92-\mathrm{kDa}$ form, and thus played a major role in tumor invasion (13). In a previous study, we found that among gulo KO mice injected with mammary 4T1 cells, those mice deprived of ascorbate developed large tumors with dark cores, showing more necrosis, and poorly defined borders, while gulo KO mice supplemented with ascorbate hosted smaller tumors with smaller, lighter cores, less necrosis and enhanced collagen encapsulation, signifying less metastatic potential (14).

High MMP-2 and MMP-9 levels have been found to correlate with aggressiveness of cancers, as exemplified by breast cancer $(15,16)$. Our present in vitro study showed dose-dependent inhibition of MMP-2 and MMP-9 secretion, cell migration and cell invasion through Matrigel with treatment of $4 \mathrm{~T} 1$ cells with NM.

A causal relationship between inflammation and 4T1 metastasis was proposed by Connolly et al based on observation of an inhibitory effect of the COX-2 inhibitor sC-236 on metastasis of $4 \mathrm{~T} 1$ after primary tumor excision (17). Inflammation has been noted to have a positive effect on metastasis in several systems $(18,19)$. The NM has been shown to have an inhibitory effect on inflammatory mediators as COX-2 in prior studies $(5,20,21)$.

Optimal ECM structure depends upon adequate supplies of ascorbic acid and the amino acids lysine and proline to ensure proper synthesis and hydroxylation of collagen fibers. In addition, lysine contributes to ECM stability as a natural inhibitor of plasmin-induced proteolysis $(4,22)$. Manganese and copper are also essential for collagen formation. There is considerable documentation of the potency of green tea extract in modulating cancer cell growth, metastasis, angiogenesis, and other aspects of cancer progression (23-27). N-acetyl cysteine and selenium have demonstrated inhibition of tumor cell MMP-9 and invasive activities, as well as migration of endothelial cells through ECM (28-30). Ascorbic acid demonstrates cytotoxic and antimetastatic actions on malignant cell lines $(14,31-35)$ and cancer patients have been found to have 

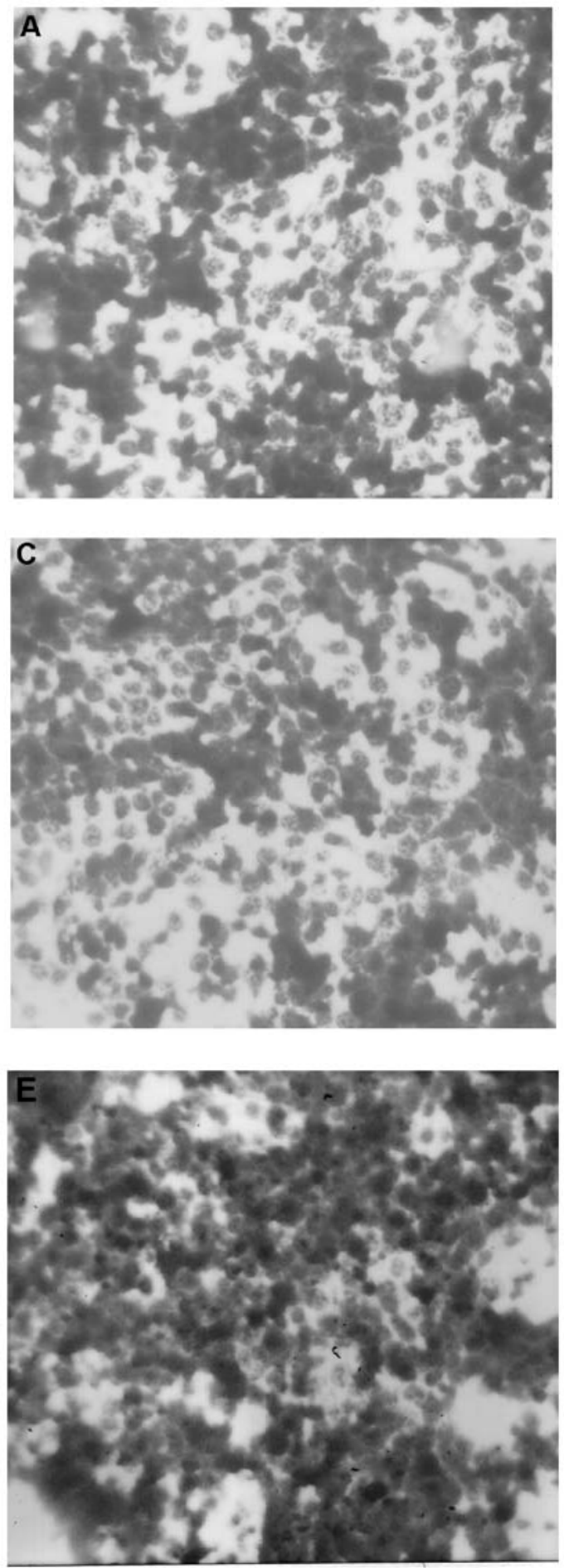
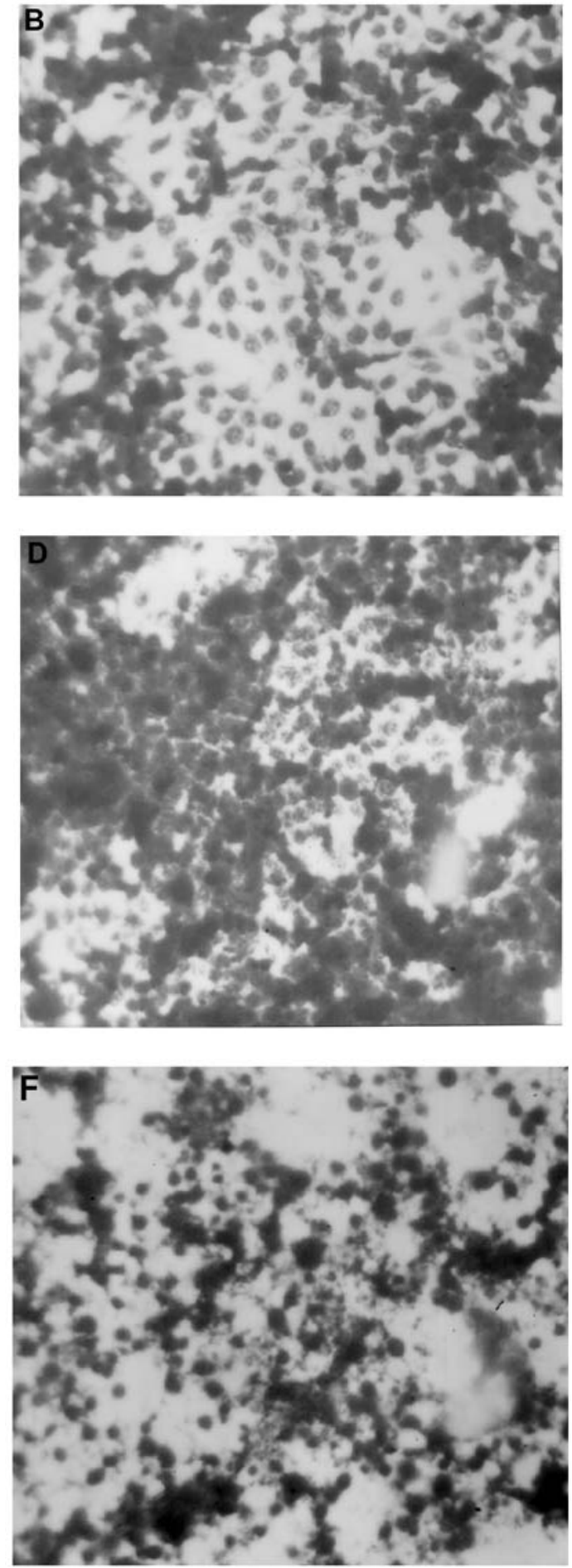

Figure 20. Effect of NM on 4T1 cell morphology: H\&E staining. (A) Control; (B) NM $50 \mu \mathrm{g} / \mathrm{ml}$; (C) NM $100 \mu \mathrm{g} / \mathrm{ml}$; (D) NM $250 \mu \mathrm{g} / \mathrm{ml}$; (E) NM 500 $\mu \mathrm{g} / \mathrm{ml}$; (F) NM $1,000 \mu \mathrm{g} / \mathrm{ml}$.

low levels of ascorbic acid (36,37). Low levels of arginine, a precursor of nitric oxide (NO), can limit the production of NO, which has been shown to predominantly act as an inducer of apoptosis (38).

In conclusion, the results of the in vivo study of murine 4T1 cells injected into the mammary pads of $\mathrm{Balb} / \mathrm{C}$ mice confirmed the validity of this model to study breast cancer metastasis since metastasis was observed in lung, liver, spleen, kidney and heart, as in human breast cancer. The present study also demonstrated significant suppression of tumor growth and metastasis to all of these organs with NM dietary supplementation, which indicates NM inhibition of metastasis is based on targeting common parameters as MMPs and the collagen barrier. Furthermore, the in vivo results were supported by in vitro findings of NM suppression of cell proliferation, secretion of MMP-2 and MMP-9, migration and Matrigel invasion by $4 \mathrm{~T} 1$ cells. These results suggest that NM has therapeutic potential in treatment of breast cancer. 


\section{Acknowledgements}

The tissues were processed by IDEXX Reference Laboratories Inc. and consulting pathologist Dr Alexander DePaoli, provided the histology slides and analysis. The research was funded by Dr Rath Health Foundation (Santa Clara, CA, USA), a non-profit organization.

\section{References}

1. American Cancer Society: Breast cancer: what are the key statistics about breast cancer? http://www.cancer.org/cancer/breastcancer/ detailedguide/breast-cancer-key-statistics). Accessed 10/9/13. Last Medical Review: 09/11/2013. Last Revised: 10/01/2013.

2. Ali SM, Harvey HA and Lipton A: Metastatic breast cancer: overview of treatment. Clin Orthop 414 (Suppl): 132-137, 2003.

3. Fidler IJ: Molecular biology of cancer: invasion and metastasis In: Cancer: Principles and Practice of Oncology. 5th edition. De Vita VT, Hellman S and Rosenberg SA (eds). Lippincott-Raven, Philadelphia, PA, pp135-152, 1997.

4. Rath M and Pauling L: Plasmin-induced proteolysis and the role of apoprotein(a), lysine and synthetic analogs. Orthomolecular Med 7: 17-23, 1992.

5. Niedzwiecki A, Roomi MW, Kalinovsky $\mathrm{T}$ and Rath M: Micronutrient synergy - a new tool in effective control of metastasis and other key mechanisms of cancer. Cancer Metastasis Rev 29: 529-543, 2010.

6. Bibby MC: Orthotopic models of cancer for preclinical drug evaluation: advantages and disadvantages. Eur J Cancer 40: 852-857, 2004.

7. Eccles SA, Box G, Court W, Sandle J and Dean CJ: Preclinical models for the evaluation of targeted therapies of metastatic disease. Cell Biophys 24-25: 279-291, 1994.

8. Hoffman RM: Orthotopic metastatic mouse models for anticancer drug discovery and evaluation: a bridge to the clinic. Invest New Drugs 17: 343-359, 1999.

9. Vernon E, Bakewell SJ and Chodash LA: Deciphering the molecular basis of breast cancer metastasis with mouse models Rev Endocr Metab Disord 8: 199-213, 2007.

10. Tao K, Fang M, Aloy J and Sahagian GG: Imagable 4T1 model for the study of late stage breast cancer. BMC Cancer 8: 228, 2008.

11. Aslakson CJ and Miller FR: Selective events in the metastatic process defined by analysis of the sequential dissemination of subpopulations of a mouse mammary tumor. Cancer Res 52: 1399-1405, 1992.

12. Bonfil RD, Bustuabad OD, Ruggiero RA, Meiss RP and Pasqualini CD: Tumor necrosis can facilitate the appearance of metastases. Clin Exp Metastasis 6: 121-129, 1988.

13. Bonfil RD, Medina PA, Gómez DE, Farías E, Lazarowski A, Lucero Gritti MF, Meiss RP and Bustuabad OD: Expression of gelatinase/type IV collagenase in tumor necrosis correlates with cell detachment and tumor invasion. Clin Exp Metastasis 10: 211-220, 1992.

14. Cha J, Roomi MW, Ivanov V, Kalinovsky T, Niedzwiecki A and Rath M: Ascorbate supplementation inhibits growth and metastasis of B16FO melanoma and $4 \mathrm{~T} 1$ breast cancer cells in vitamin C deficient mice. Int J Oncol 42: 55-64, 2013.

15. Bachmeier BE, Nerlich AG, Lichtinghagen R and SommerhoffCP: Matrix metalloproteinases (MMPs) in breast cancer cell lines of different tumorigenicity. Anticancer Res 6A: 3821-3828, 2001.

16. Pellikainen JM, Ropponen KM, Kataja VV, Kellokoski JK, Eskelinen MJ and Kosma VM: Expression of matrix metalloproteinase (MMP)-2 and MMP-9 in breast cancer with a special reference to activator protein-2, HER-2, and prognosis. Clin Cancer Res 10: 7621-7628, 2004.

17. Connolly EM, Harmey JH O'Grady T, Foley D, Roche-Nagle G, Kay E and Bouchier-Hayes DJ: Cyclo-oxygenase inhibition reduces tumour growth and metastasis in an orthotopic model of breast cancer. Br J Cancer 87: 231-237, 2002.

18. Denardo DG, Johansson M and Coussans LM: Immune cells as mediators of solid tumor metastasis. Cancer Metastasis Rev 27: 11-18, 2008.
19. van Kempen LC, de Visser KE and Coussens LM: Inflammation, proteases and cancer. Eur J Cancer 42: 728-734, 2006.

20. Roomi MW, Kalinovsky T, Roomi NW, Rath $M$ and Niedzwiecki A: Inhibition of growth and expression of inflammation mediators in human leukemic cell line. Exp Oncol 35: 180-186, 2013.

21. Roomi MW, Kalinovsky T, Niedzwiecki A and Rath M: Pleiotropic effects of a micronutrient mixture on critical parameters of bladder cancer. In: Bladder Cancer Etymology, Diagnosis and Treatments. Nilsson WE (ed). Nova Science Publishers, Inc., New York, 2009.

22. Sun Z, Chen YH, Wang P, Zhang J, Gurewich V, Zhang P and Liu JN: The blockage of high-affinity lysine binding sites of plasminogen by EACA significantly inhibits prourokinase-induced plasminogen activation. Biochem Biophys Acta 1596: 182-192, 2002.

23. Valcic S, Timmermann BN, Alberts DS, Wachter GA, Krutzsch M, Wymer J and Guillen JM: Inhibitory effect of six green tea catechins and caffeine on the growth of four selected human tumor cell lines. Anticancer Drugs 7: 461-468, 1996.

24. Mukhtar H and Ahmed N: Tea polyphenols: prevention of cancer and optimizing health. Am J Clin Nutr 71: S1698-S1702, 2000.

25. Yang GY, Liao J, Kim K, Yurtow EJ and Yang CS: Inhibition of growth and induction of apoptosis in human cancer cell lines by tea polyphenols. Carcinogenesis 19: 611-616, 1998.

26. Taniguchi S, Fujiki H, Kobayashi H, Go H, Miyado K, Sadano H and Shimikawa R: Effect of (-) epigallocatechin gallate, the main constituent of green tea, on lung metastasis with mouse B16 melanoma cell lines. Cancer Lett 65: 51-54, 1992.

27. Hara Y: Green tea: Health Benefits and Applications. Marcel Dekker, New York, Basel, 2001.

28. Kawakami S, Kageyama Y, Fujii Y, Kihara K and Oshima H: Inhibitory effects of $\mathrm{N}$-acetyl cysteine on invasion and MMP 9 production of T24 human bladder cancer cells. Anticancer Res 21: 213-219, 2001.

29. Morini M, Cai T, Aluigi MG, Noonan DM, Masiello L, De Floro S, D'Agostinin F, Albini A and Fassima G: The role of the thiol $\mathrm{N}$-acetyl cysteine in the prevention of tumor invasion and angiogenesis. Int J Biol Markers 14: 268-271, 1999.

30. Yoon SO, Kim MM and Chung AS: Inhibitory effects of selenite on invasion of HT 1080 tumor cells. J Biol Chem 276: 20085-20092, 2001.

31. Naidu KA, Karl RC and Coppola D: Antiproliferative and proapoptotic effect of ascorbyl stearate in human pancreatic cancer cells: association with decreased expression of insulinlike growth factor 1 receptor. Dig Dis Sci 48: 230-237, 2003.

32. Anthony HM and Schorah CJ: Severe hypovitaminosis C in lung-cancer patients: the utilization of vitamin $\mathrm{C}$ in surgical repair and lymphocyte-related host resistance. Br J Cancer 46: 354-367, 1982.

33. Maramag C, Menon M, Balaji KC, Reddy PG and Laxmanan S: Effect of vitamin $C$ on prostate cancer cells in vitro: effect on cell number, viability and DNA synthesis. Prostate 32: 188-195, 1997.

34. Koh WS, Lee SJ, Lee H, Park C, Park MH, Kim WS, Yoon SS, Park K, Hong SI, Chung MH and Park CH: Differential effects and transport kinetics of ascorbate derivatives in leukemic cell lines. Anticancer Res 8: 2487-2493, 1998.

35. Chen Q, Espey MG, Krishna MC, Mitchell JB, Corpe CP, Buettner GR, Shacter E and Levine M: Pharmacologic ascorbic acid concentrations selectively kill cancer cells: Action as a pro-drug to deliver hydrogen peroxide to tissues. Proc Natl Acad Sci USA 102: 13604-13609, 2005.

36. Nunez C, Ortiz de Apodaca Y and Ruiz A: Ascorbic acid in the plasma and blood cells of women with breast cancer. The effect of consumption of food with an elevated content of this vitamin. Nutr Hosp 10: 368-372, 1995.

37. Kurbacher CM, Wagner U, Kolster B, Andreotti PE, Krebs D and Bruckner HW: Ascorbic acid (vitamin C) improves the antineoplastic activity of doxorubicin, cisplatin and paclitaxel in human breast carcinoma cells in vitro. Cancer Lett 103: 183-189, 1996.

38. Cooke JP and Dzau VJ: Nitric oxide synthase: role in the genesis of vascular disease. Annu Rev Med 48: 489-509, 1997. 